\title{
Isotopic evidence for a Precambrian metamorphic event within the Charcot Land window, East Greenland Caledonian fold belt
}

\author{
B. T. HANSEN, R. H. STEIGER AND A. K. HIGGINS
}

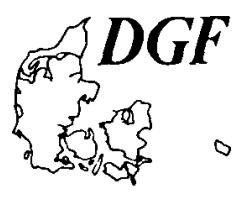

\begin{abstract}
Hansen, B. T., Steiger, R. H. and Higgins, A. K.: Isotopic evidence for a Precambrian metamorphic event within the Charcot Land window, East Greenland Caledonian fold belt. Bull. geol. Soc. Denmark, vol. 29, pp. 151-160, Copenhagen, January 19th, 1981. https://doi.org/10.37570/bgsd-1980-29-10

$\mathrm{Rb}-\mathrm{Sr}, \mathrm{U}-\mathrm{Pb}$ and $\mathrm{K}-\mathrm{Ar}$ analyses on rocks and minerals from a tectonic window below a Caledonian thrust sheet in the westernmost part of the Scoresby Sund region $\left(70^{\circ}-72^{\circ} \mathrm{N}\right)$ give evidence for a Precambrian age of formation. The Charcot Land supracrustal sequence rests on a basement that is probably of Archaean development and older than at least 2100 m.y. The major regional metamorphism of the supracrustal rocks is probably not much older than the intrusion of two post-kinematic bodies, i.e. about 1840 m.y. Low-grade metamorphism in a tillite and low-grade retrogressive overprinting of the supracrustal rocks are related to Caledonian orogenesis.
\end{abstract}

B. T. Hansen* and R. H. Steiger, Institut für Kristallographie und Petrographie, Eidgenössische Technische Hochschule Zürich, Sonneggstrasse 5, CH-8092 Zürich, Switzerland.

A. K. Higgins, Grønlands Geologiske Undersøgelse, Øster Voldgade 10, DK-1350 København K, Denmark, May 13th, 1980.

Several tectonic windows occur in Caledonian thrust sheets in the western part of the Scoresby Sund region $\left(70^{\circ}-72^{\circ} \mathrm{N}\right)$ in East Greenland; these expose autochthonous or parautochthonous areas of the Caledonian foreland. One of the largest windows includes the greater part of Charcot Land (fig. 1), and exposes basement gneisses and amphibolites, an extensive suite of supracrustal rocks, major intrusions and a tillite.

The Charcot Land supracrustal sequence was first studied by P. Vogt and E. Wenk in north-west Hinks Land (Vogt 1965). A major thrust was recognised between the Charcot Land supracrustal sequence and the overlying Krummedal supracrustal sequence, but only limited displacement was assumed and both supracrustal sequences were assigned to the lower part of the late Precambrian Eleonore Bay Group. Much of the region was mapped by $A$. Steck in 1968 in the course of systematic mapping in the Scoresby Sund region by the Geological Survey of Greenland (GGU). The first results of the Survey mapping were outlined by Henriksen \& Higgins (1969), and it was established that the Charcot
Land region occupies a dome-like position beneath a major arcuate thrust with a westward displacement of at least $40 \mathrm{~km}$ (fig. 1). Steck (1971) described the progressive regional metamorphism which affected the Charcot Land supracrustal sequence and suggested it was of Caledonian age.

The infracrustal basement complex of Charcot Land consists mainly of banded gneisses, augen gneisses and amphibolites. These are overlain by the Charcot Land supracrustal sequence which is at least $2000 \mathrm{~m}$ thick; however, the basement and cover are deformed together so that an original unconformity can no longer be discerned. The lowest part of the supracrustal sequence includes prominent marble and greenschist or amphibolite units. Semipelitic and quartzitic units are widespread, while the Royston Nunatakker south of Charcot Land consist largely of basic extrusives; pillow structures have been noted at several localities. There is a pronounced lateral variation in development of the various supracrustal units. A number of hornblende gabbro intrusions found in the supracrustals in southern Charcot Land are

\footnotetext{
* Present address: Institut für Mineralogie, Universität Münster, Gievenbecker Weg 61, D-4400 Münster, Germany.
} 
considered to be comagmatic with the basic extrusives (Steck 1971).

The southern areas of supracrustals are characterised by a low greenschist facies metamorphism in sharp contrast to the high grade rocks of the overlying Caledonian thrust sheet. Northwards there is a pronounced progressive increase in metamorphic grade, and high amphibolite facies is reached in the supracrustals in north-east Charcot Land (Steck 1971).

Two late to post-kinematic intrusions outcrop in Charcot Land. The smaller body occupies most of Tillit Nunatak and is mainly a hornblende-biotite quartz diorite. It shows slight alteration attributed to retrogressive metamorphism. It is emplaced largely in the infracrustal basement unit, but also veins the supracrustal sequence. $\mathrm{U}-\mathrm{Pb}$ analyses of zircons from the quartz diorite (Steiger \& Henriksen 1972), suggest a minimum age of intrusion of $1900 \mathrm{~m} . \mathrm{y}$., which implies that the supracrustal rocks are also at least 1900 m.y. old; further observations on the zircons are given below. The larger intrusive body is a very prominent coarse-grained to pegmatitic, leucocratic muscovite granite which crops out over an area of 25 by $10 \mathrm{~km}$. A marginal network of pegmatite veins and dykes cuts the infracrustal gneisses and the supracrustals. This body has previously been interpreted as a post-kinematic Caledonian granite (Haller 1971, p. 286).

The (Vendian?) tillite of Tillit Nunatak is several hundred metres thick, occupies an area of 500 by $1500 \mathrm{~m}$ and rests unconformably on the 1900 m.y. old quartz diorite intrusion (Henriksen, in press).

Results are given of $\mathrm{Rb}-\mathrm{Sr}, \mathrm{U}-\mathrm{Pb}$ and $\mathrm{K}-\mathrm{Ar}$ analyses undertaken on samples from the infracrustal basement complex, the supracrustal sequence, and the quartz diorite and pegmatite granite intrusions. Samples derive from the collections of N. Henriksen and A. Steck, and special collecting undertaken by B.T.H. in 1972 . Analyses were performed in the geochronological laboratories of the Eidgenössische Technische Hochschule Zürich. Analytical procedures for the $\mathrm{Rb}-\mathrm{Sr}$ and $\mathrm{U}-\mathrm{Pb}$ analyses have recently been fully

Fig. 1. Geological sketch map of the Charcot Land area. Inset shows the location of Charcot Land (arrowed) and the extent of the East Greenland Caledonian fold belt (shaded).

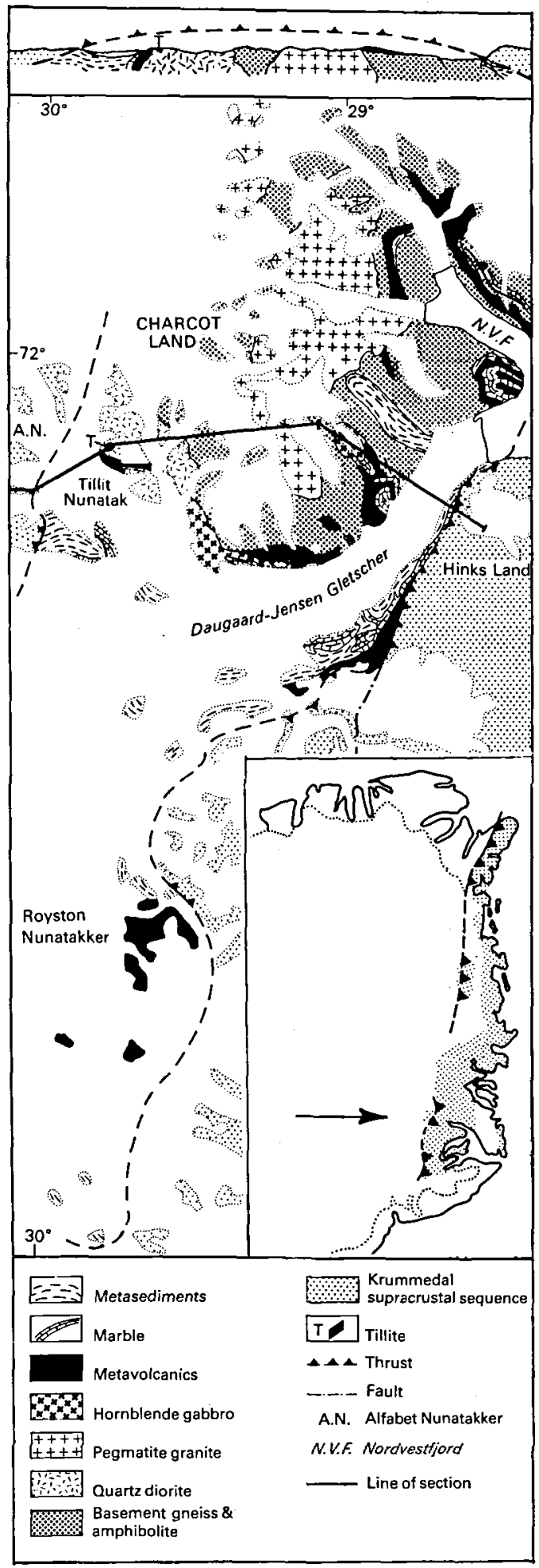


described in Steiger et al. (1979). All data were computed using the constants recommended by the subcommission on geochronology (Steiger \& Jäger 1977), and ages quoted from earlier work have been recalculated with these constants. Regression analyses were performed using the least squares method of York (1969). All errors quoted correspond to 20 .

\section{The Charcot Land infracrustal complex}

Hornblende separated from amphibolite bands within the basement gneisses of Charcot Land gave $\mathrm{K}-\mathrm{Ar}$ ages of $2855 \pm 145 \mathrm{~m}$.y. (166820) and $2097 \pm 105$ m.y. (166818), respectively. A replicate argon determination on sample 166818 gave an age of $2075 \pm 105$ m.y. (table 1 ). We regard these as minimum ages for the infracrustal complex. The ages are in broad agreement with results from the Flyverfjord infracrustal complex exposed east of Charcot Land and made up of comparable rock units, where Rex \& Gledhill (1974), Rex et al. (1977) and Steiger et al. (1979) have obtained Rb-Sr, U-Pb and K-Ar data indicating ages in the range 2300-2900 m.y. One of the K-Ar hornblende ages from Charcot Land gave a younger age (1750 \pm 90 m.y.: sample 166821). This sample originated from a locality where the amphibolite is veined by pegmatite granite, and as the age agrees (within limits of error) with $\mathrm{Rb}-\mathrm{Sr}$ whole-rock ages of $1835 \pm 50$ m.y. obtained from this body it probably indicates a resetting of the $\mathrm{K}-\mathrm{Ar}$ system at the time of intrusion of the pegmatite granite. The age of $642 \pm 25 \mathrm{~m}$.y. on an amphibolite from extreme eastern Charcot Land represents partial Caledonian resetting (see below).

\section{Pegmatite granite}

The pegmatite granite intrusion occupies wide areas in the central part of Charcot Land. Six samples were analysed for $\mathrm{Rb}-\mathrm{Sr}$ isotopes (table 2, fig. 2). A regression line based on five of the six points (omitting sample 4) corresponds to an age of $1835 \pm 50$ m.y. (M.S.W.D. $=6.5$ ).

The position of data point 4 possibly reflects the influence of Caledonian overprinting. The sample contains $80 \%$ plagioclase and less than $5 \%$ mica (table 5 ), and the relatively high concentration of radiogenic $\mathrm{Sr}$ may arise from absorption by the plagioclase during incomplete isotopic redistribution related to the Caledonian disturbance.

The slope of the 1835 m.y. "isochron" is largely controlled by the sample having the highest ${ }^{87} \mathrm{Rb} /{ }^{86} \mathrm{Sr}$ ratio, but even if this point (6) is not used in the calculation, an age of $1900 \pm 35$ m.y. is obtained. As both ages agree within limits of error we believe that an age of about 1850 m.y.

\begin{tabular}{|c|c|c|c|c|c|c|}
\hline GGU sample & & & $\mathrm{ccm}^{40} \mathrm{Ar}$ & Atmos. ${ }^{40} \mathrm{Ar}$ & & \\
\hline No. & Rock type & Mineral & $9 \times 10^{8}$ & $\%$ & wt. $\mathrm{k}$ & Age $m \cdot y$. \\
\hline Charcot Land & infracrustals & & & & - & \\
\hline 117363 & Amphibolite & Hornblende & 1007 & 4.70 & $0.336^{*}$ & $642 \pm 25$ \\
\hline 166818 & Amphibolite & Hornblende & 9396 & 0.93 & $0.611^{+}$ & $2097 \pm 105$ \\
\hline 166818 & Amphibolite & Hornblende & 9257 & 0.71 & $0.611^{+}$ & $2075 \pm 105$ \\
\hline 166820 & Amphibolite & Hornblende & 9831 & 0.23 & $0.362^{+}$ & $2855 \pm 145$ \\
\hline 166821 & Amphibolite & Hornblende & 4246 & 0.12 & $0.370^{+}$ & $1750 \pm 90$ \\
\hline \multicolumn{7}{|c|}{ Pegmatite-granite intrusion } \\
\hline 103795 & Pegmatite & Muscovite & 87850 & 2.80 & $7.58^{*}$ & $1760 \pm 60$ \\
\hline 103795 & Pegmatite & Muscovite & 96750 & 3.00 & $7.58^{*}$ & $1870 \pm 60$ \\
\hline
\end{tabular}

\footnotetext{
* Analyses for $K$ made by atomic absorption by R. Heusser, Zürich

+ Analyses for $K$ made by isotope dilution
}

Table 1. K-Ar analytical data. 


\begin{tabular}{|c|c|c|c|c|c|c|c|}
\hline $\begin{array}{c}\text { GGU sample } \\
\text { No. }\end{array}$ & $\begin{array}{l}\text { No, in } \\
\text { Fig. }\end{array}$ & $\begin{array}{l}\text { Type of } \\
\text { sample }\end{array}$ & $\begin{array}{l}\mathrm{Rb} \\
\mathrm{PPm}\end{array}$ & $\begin{array}{l}\mathrm{Sr} \\
\mathrm{\rho pm}\end{array}$ & ${ }^{87} \mathrm{Rb} /{ }^{86} \mathrm{Sr}$ & ${ }^{87} \mathrm{Sr} /{ }^{86} \mathrm{Sr}$ & Age in m.y. \\
\hline \multicolumn{8}{|c|}{ Pegmatite-granite } \\
\hline 166823 & 4 & Whole-rock & 334 & 94.9 & 10.6 & 1.149 & \\
\hline 166830 & 5 & Whole-rock & $\$ 4.9$ & 9.76 & 17.1 & 1.201 & \\
\hline 166822 & 3 & Whole-rock & 182 & 59.3 & 9.13 & 0.981 & \\
\hline 166828 & 6 & Whole-rock & 284 & 11.1 & 90.51 & 2.998 & $1835 \pm 50$ \\
\hline 103798 & 1 & Whole-rock & 34.8 & 41.9 & 2.34 & 0.7966 & \\
\hline 103799 & 2 & Whole-Iock & 193 & 139 & 4.05 & 0.8132 & \\
\hline 103799 & & $K-F e l d s p a r$ & 281 & 111 & 7.42 & 0.8275 & $402 \pm 8$ \\
\hline 103799 & & Biotite & 1369 & 14.6 & 323 & 2.666 & . \\
\hline 103799 & & Muscovite & 623 & 31.5 & 67.9 & 2.254 & $1585 \pm 50$ \\
\hline \\
\hline 117363 & & Biotite & 348 & 10.7 & 99.3 & 1.279 & $402 \pm 10$ \\
\hline
\end{tabular}

${ }^{87} \mathrm{Sr} /{ }^{86} \mathrm{Sr}$ normalized to ${ }^{86} \mathrm{Sr} /{ }^{88} \mathrm{Sr}=0.1194$

Estimated errors $(2 \sigma)$ bused on replicate analyses are ${ }^{87} \mathrm{Rb} /{ }^{86} \mathrm{Sr}=2 \%,{ }^{87} \mathrm{Sr} /{ }^{86} \mathrm{Sr}=0.1 \%$

Muscovite-age based on muscovite-whole-rock tie-line

Table 2. Rb-Sr analytical data.

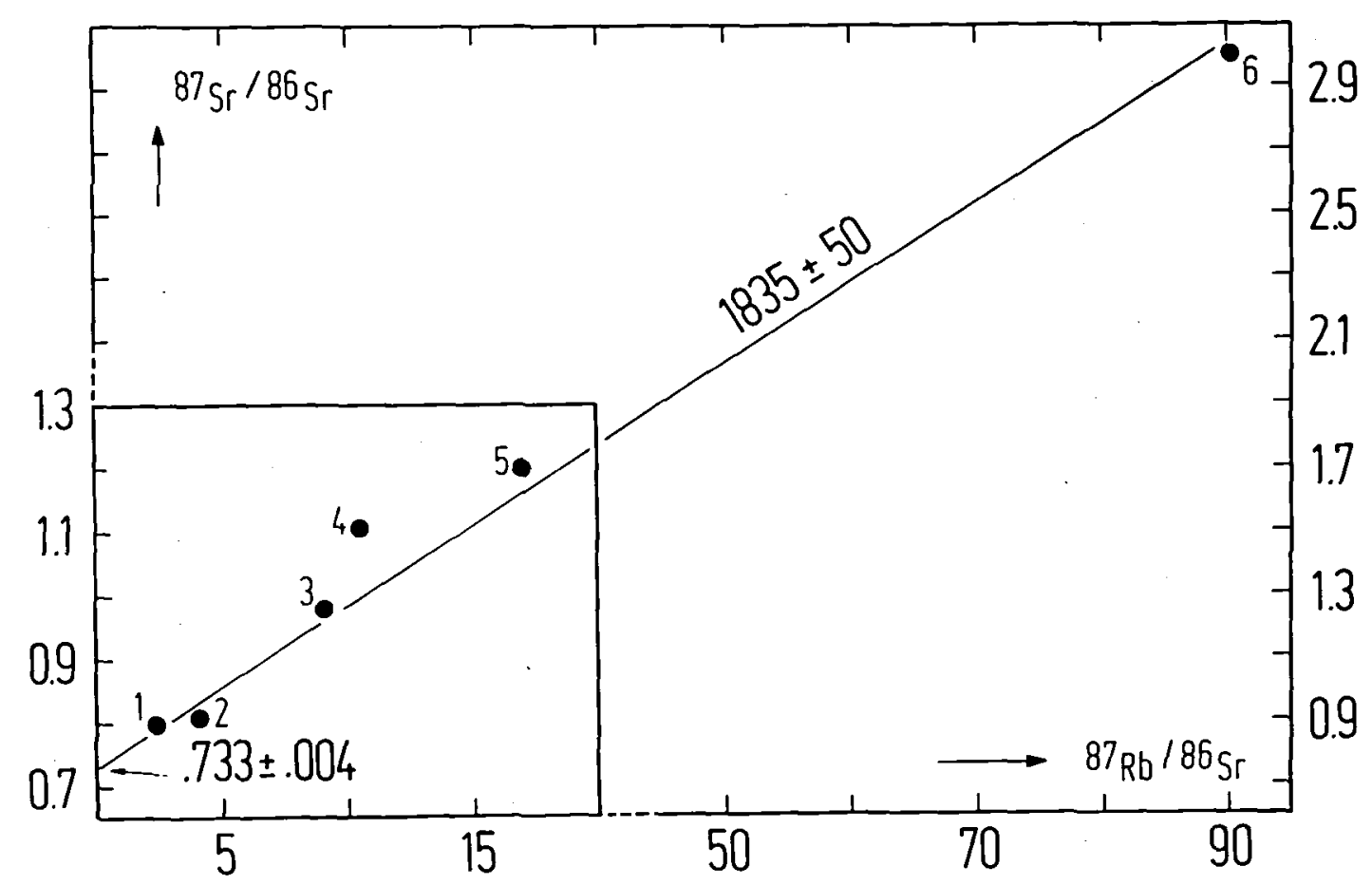

Fig. 2. Rb-Sr diagram for whole rock analyses of the pegmatite granite intrusion. 
represents the approximate time of intrusion of the pegmatite granite.

$\mathrm{K}$-Ar analyses on large muscovite crystals (sample 103795) from the coarse-grained part of the same pegmatite granite indicate a minimum age for the intrusion in the 1760-1870 m.y. range (table 1).

Field observations by Steck (1971) indicate that the pegmatite granite was emplaced after the main metamorphic event affecting the supracrustal rocks, and the ages obtained on the granite thus give a minimum age for the metamorphic event.

Hornblende-biotite quartz diorite

The hornblende-biotite quartz diorite forms most of Tillit Nunatak, and as offshoots from the intrusion also vein the supracrustals (Steck 1971), determination of the age of the quartz diorite also gives a minimum age for the deposition and metamorphism of the Charcot Land supracrustal sequence.

At the collection site of the zircon samples the quartz diorite is completely homogeneous, but in other places it may be foliated and include gneiss and amphibolite inclusions. U-Pb zircon data (ta- ble 3, fig. 3) show a limited spread in the $\mathrm{U} / \mathrm{Pb}$ ratios, are highly discordant and do not form a linear array. The low ${ }^{206} \mathrm{~Pb} /{ }^{204} \mathrm{~Pb}$ ratios indicate that $11-20 \%$ of the $\mathrm{Pb}$ content in the zircons is common $\mathrm{Pb}$; however, no plausible common $\mathrm{Pb}$ correction will cause the data points to fall in line. Several interpretations are possible:

1. Best fit straight lines based on York (1969) and using various common $\mathrm{Pb}$ corrections and correlation coefficients yield intersections with the concordia curve varying from 1805 to 1917 m.y. and from 295 to 331 m.y. Applying the common $\mathrm{Pb}$ correction shown in table 3 , a correlation coefficient of 0.7 (Pidgeon 1978) and individual errors in $\mathrm{x}$ and $\mathrm{y}$ corresponding to 2 standard errors of the ${ }^{207} \mathrm{~Pb} /{ }^{206} \mathrm{~Pb}$ ratios (table 3), an upper intercept of 1822 m.y. and a lower intercept of 301 m.y. are obtained. However, both values have large errors due to the non-linearity of the data. While the upper intersection can be interpreted as the time of intrusion, it is unlikely that the age inferred from the lower intercept reflects a metamorphic event; we suggest it might be the result of a relief of confining pressure (Goldich \&

\begin{tabular}{|c|c|c|c|c|c|c|c|c|c|}
\hline $\begin{array}{l}\text { No. in } \\
\text { fig. }\end{array}$ & $\begin{array}{r}\text { Sieve } \\
\mu\end{array}$ & fraction & $\begin{array}{l}\text { mg sample } \\
\text { analysed }\end{array}$ & $\begin{array}{l}\mathrm{u} \\
\mathrm{ppm}\end{array}$ & $\begin{array}{l}\text { Th } \\
\text { ppm }\end{array}$ & $\begin{array}{l}\mathrm{Pb} \\
\mathrm{ppm}\end{array}$ & $\begin{array}{l}\text { Moles } x \\
238 \mathrm{u}\end{array}$ & $\begin{array}{l}10^{-9} / \mathrm{g} \\
232 \mathrm{Th}\end{array}$ & $\begin{array}{l}\text { sample } \\
206 \mathrm{~Pb}\end{array}$ \\
\hline 13 & $<175$ & $M M$ & 121.3 & 1371 & 264.9 & 155.5 & 5717 & 1141 & 560.2 \\
\hline 14 & $<175$ & M & 67.9 & 1377 & 253.4 & 144.9 & 5743 & 1092 & 542.4 \\
\hline 15 & $<175$ & $M$ & 90.7 & 1477 & 256.2 & 156.7 & 6161 & 1104 & 568.2 \\
\hline 19 & $<175$ & NM & 162.0 & 1150 & 189.3 & 128.0 & 4796 & 816 & 484.9 \\
\hline 20 & $<175$ & LM & 145.0 & 1031 & 170.4 & 124.0 & 4298 & 734 & 468.2 \\
\hline 21 & $<175$ & I & 441.7 & 1299 & 223.9 & 128.0 & 5416 & 965 & 492.2 \\
\hline
\end{tabular}

\begin{tabular}{|c|c|c|c|c|c|c|c|c|c|}
\hline $\begin{array}{l}\text { No. in } \\
\text { fig. }\end{array}$ & $\begin{array}{l}\text { Observed atom } \\
206 \mathrm{~Pb} / 204 \mathrm{~Pb}\end{array}$ & $\begin{array}{l}\text { mic ratios } \\
207 \mathrm{~Pb} / 206 \mathrm{~Pb}\end{array}$ & $207_{\mathrm{Pb}} /^{208_{\mathrm{Pb}}}$ & $\begin{array}{l}\text { Atomic ratio } \\
206 \mathrm{~Pb} /{ }^{238} \mathrm{u}\end{array}$ & $\begin{array}{l}207 \mathrm{~Pb} /{ }^{235} \mathrm{U}\end{array}$ & $\begin{array}{l}\text { for blank a } \\
208 \mathrm{~Pb} / 232 \mathrm{Th}\end{array}$ & $\begin{array}{l}\text { nd common } \\
207_{\mathrm{Pb} /} 20\end{array}$ & $\begin{array}{c}\mathrm{Pb} \\
06_{\mathrm{Pb}}\end{array}$ & ${ }^{207} \mathrm{~Pb} /{ }^{208} \mathrm{~Pb}$ \\
\hline 13 & 273.4 & 0.13260 & 0.6366 & 0.0923 & 1.0263 & 0.03878 & 0.08061 & $(40)^{*}$ & 0.9612 \\
\hline 14 & 369.8 & 0.12246 & 0.7233 & 0.0904 & 1.0492 & 0.03660 & 0.08417 & $(23)$ & 1.0931 \\
\hline 15 & 276.3 & 0.13381 & 0.6717 & 0.0870 & 0.9887 & 0.03668 & 0.08246 & $(27)$ & 1.0906 \\
\hline 19 & 388.2 & 0.12364 & 0.8058 & 0.0970 & 1.1674 & 0.03708 & 0.08729 & $(22)$ & 1.3423 \\
\hline 20 & 382.2 & 0.12649 & 0.8162 & 0.1044 & 1.2916 & 0.03989 & 0.08970 & $(20)$ & 1.3747 \\
\hline 21 & 469.8 & 0.11579 & 0.8131 & 0.0878 & 1.0377 & 0.03425 & 0.08570 & $(18)$ & 1.2331 \\
\hline
\end{tabular}

Relative magnetic susceptibility: MM = highest, $M=$ high, $I=$ intermediate, NM = low, LM = lowest Data corrected for blank of $7 \times 10^{-10} \mathrm{~mol} \mathrm{~Pb}$. Isotopic composition:

${ }^{206} \mathrm{~Pb} /{ }^{204} \mathrm{~Pb}=17.66,{ }^{207} \mathrm{~Pb} /{ }^{204} \mathrm{~Pb}=15.26,{ }^{208} \mathrm{~Pb} /{ }^{204} \mathrm{~Pb}=37.04$

Composition of common $\mathrm{Pb}$ used for correction:

${ }^{206} \mathrm{~Pb} /{ }^{204} \mathrm{~Pb}=15.80,{ }^{207} \mathrm{~Pb} /{ }^{204} \mathrm{~Pb}=15.49,208 \mathrm{~Pb} /{ }^{204} \mathrm{~Pb}=35.35$

* In brackets: 2 standard errors shown as the least significant digits of $207 \mathrm{~Pb} /{ }^{206} \mathrm{~Pb}$ ratios.

Table 3. U-Th-Pb analytical data for GGU sample 103779 (borax fusion method). 


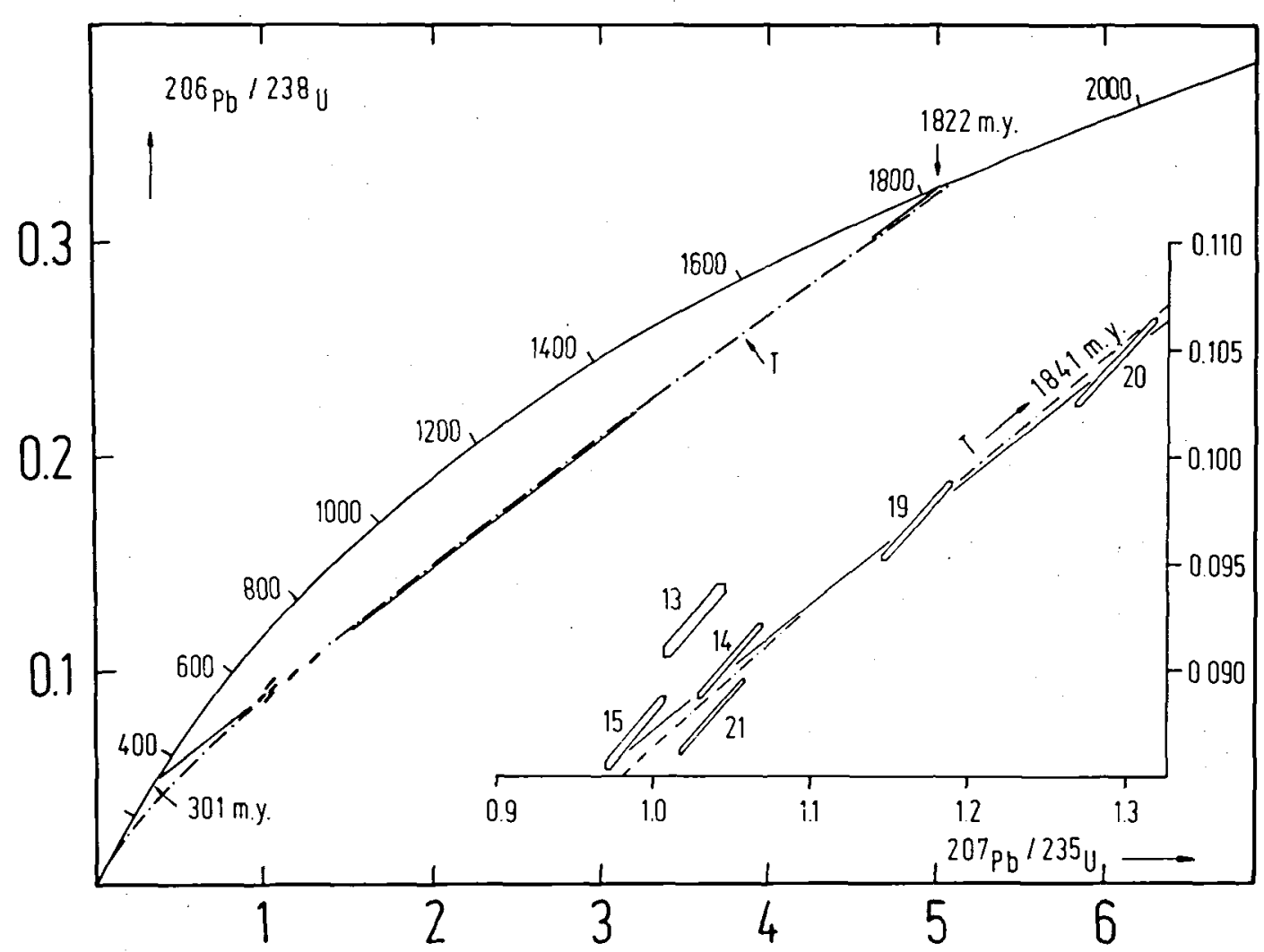

Fig. 3. ${ }^{206} \mathrm{~Pb} /{ }^{238} \mathrm{U}-{ }^{207} \mathrm{~Pb} /{ }^{235} \mathrm{U}$ plot for zircon fractions of the hornblende-biotite quartz diorite intrusion (GGU sample 103779). The dash-dot line $T$ is the best fit continuous diffusion curve $\left(D=D_{0}\right.$, Tilton 1960).

Mudray 1972) leading to dehydration of the zircons and resulting in Pb loss. Haller (1971, p. 312) relates a break in sedimentation in lower Carboniferous time to regional uplift. A similar explanation was suggested by Steiger et al. (1979) for zircon results farther east in the Scoresby Sund area.

2. Pure continuous $\mathrm{Pb}$ diffusion since the time of emplacement of the hornblende-biotite quartz diorite provides an alternative interpretation of the data. A best fit continuous diffusion curve $T$ (Tilton 1960) shown in fig. 3 intersects the concordia curve at 1841 m.y.

3. Continuous diffusion superimposed by a pulse of metamorphism (Wetherill 1963, fig. 1) is perhaps the most plausible interpretation. If the zircons from Tillit Nunatak were affected by the Caledonian metamorphism, as indicated by the occurrence of Caledonian $\mathrm{Rb}-\mathrm{Sr}$ mineral ages in the area, the age of 1841 m.y. must be regarded as a minimum age for the intrusion of the quartz diorite.

The morphology of the Tillit Nunatak zircons is very unusual. The grains form turbid, reddish brown, rod-like to tabular fragments of irregular shape, often intercalated with layers of milky material. Many grains exhibit cleavage but rarely any crystal faces. There is no evidence for the presence of more than one generation of zircons. The zircons may represent a special type which is particularly susceptible to lead loss. The fact that the zircons are strongly discordant makes it difficult to establish whether they are as uniform in age as they appear morphologically. If the quartz diorite was formed by mobilisation of a metasedimentary rock, obvious indications of its previous history are lacking from the zircon data, 
and complete resetting of the zircon clock at the time of formation of the intrusion must be assumed.

\section{Charcot Land supracrustal sequence}

Metagabbro bodies occur within the supracrustal rocks of Charcot Land as regular intrusive bodies with sharp contacts which are mostly parallel to the schistosity of the sediments. They are considered to be related to the associated basic extrusive rocks (Steck 1971). The preexisting structure of the gabbros has been largely retained during the regional metamorphism event which caused a uralitisation of the minerals.

$\mathrm{U}-\mathrm{Pb}$ data for zircons from the gabbro (table 4, fig. 4) show only a limited spread in U-Pb ratios and the high discordancy of the data points make the significance of the concordia intersection age of $2024 \pm{ }_{109}^{138}$ m.y. questionable. If a simple episodic lead loss model is assumed related to a Caledonian event, an age of about 1900 m.y. is obtained for the intrusion. If we assume a diffusion model as suggested by Wasserburg (1963) a minimum age of 1840 m.y. for the intrusion is obtained. The zircon morphology indicates a complicated history. They form turbid, brownish, long prismatic crystals. Many grains exhibit euhedral shapes with well developed pyramidal faces, but tabular fragments of irregular shape are also found. The majority of the grains show multiple growth around alder cores and at least three distinct zones can be recognised. Nearly all crystals are fractured and inclusions are common.

The U-Pb data from the metagabbro are broadly similar to the $\mathrm{Rb}-\mathrm{Sr}$ and $\mathrm{U}-\mathrm{Pb}$ data from the pegmatite granite and quartz diorite. The time of metamorphism of the Charcot Land supracrustal sequence should lie between the age of the metagabbro and that of the two post-kinematic intrusions, but cannot be stated precisely because of the difficulty of interpreting the data; an age between $2024-1835$ m.y. is possible, and $1900-1850 \mathrm{~m} . y$. perhaps most likely for the time of metamorphism.

\section{Influence of the Caledonian orogeny}

Although Steck (1971) believed that the Charcot Land supracrustal sequence had only been involved in a single regional metamorphism, there is some petrological and isotopic evidence for a

\begin{tabular}{|c|c|c|c|c|c|c|}
\hline $\begin{array}{l}\text { No. in } \\
\text { fig. }\end{array}$ & $\begin{array}{c}\text { Sieve fraction } \\
\mu \mathrm{m}\end{array}$ & $\begin{array}{l}\text { mg sample } \\
\text { analysed }\end{array}$ & $\begin{array}{c}\mathrm{u} \\
\mathrm{ppm}\end{array}$ & $\begin{array}{l}\mathrm{Pb} \\
\mathrm{ppm}\end{array}$ & $\begin{array}{c}\text { Moles } x \\
238_{U}\end{array}$ & $\begin{array}{c}\times 10^{-9} / 9 \text { sample } \\
206 \mathrm{~Pb}\end{array}$ \\
\hline A & $<46$ & 1.1 & 224 & 50.0 & 1020 & 191.2 \\
\hline B & $61-80$ & 6.8 & 453 & 95.4 & 1892 & 360.8 \\
\hline$c$ & $>125$ & 11.4 & 490 & 107.8 & 2042 & 409.6 \\
\hline
\end{tabular}

\begin{tabular}{|c|c|c|c|c|c|c|}
\hline $\begin{array}{l}\text { No. in } \\
\text { fig. }\end{array}$ & $\begin{array}{l}\text { Observed ato } \\
206 \mathrm{~Pb} / 204 \mathrm{~Pb}\end{array}$ & $\begin{array}{l}\mathrm{mic} \text { ratios } \\
207 \mathrm{~Pb} /{ }^{206} \mathrm{~Pb}\end{array}$ & ${ }^{208} \mathrm{~Pb} / 206 \mathrm{~Pb}$ & $\begin{array}{l}\text { corrected } \\
206 \mathrm{~Pb} /{ }^{238} \mathrm{U}\end{array}$ & $\begin{array}{l}\text { tomic ratios } \\
\text { or blank and } \\
207 \mathrm{~Pb} / 235 \mathrm{U}\end{array}$ & $\begin{array}{l}\text { common } \mathrm{Pb} \\
207 \mathrm{~Pb} / 206 \mathrm{~Pb}\end{array}$ \\
\hline A & 22530 & 0.10371 & 0.16329 & 0.1874 & 2.6605 & $0.10309(22)^{*}$ \\
\hline B & 1335 & 0.11523 & 0.16534 & 0.1884 & 2.7211 & $0.10486(10)$ \\
\hline c & 1902 & 0.11363 & 0.16125 & 0.1989 & 2.9135 & 0.10637 (7) \\
\hline
\end{tabular}

Data corrected for blank of $3.5 \times 10^{-11}$ mol. Pb. Isotapic composition:

${ }^{206} \mathrm{~Pb} /{ }^{204} \mathrm{~Pb}=17.46,{ }^{207} \mathrm{~Pb} /{ }^{204} \mathrm{~Pb}=15.25,{ }^{208} \mathrm{~Pb} / 204 \mathrm{~Pb}=36.65$

Composition of common Pb used for correction:

${ }^{206} \mathrm{~Pb} /{ }^{204} \mathrm{~Pb}=15.8,{ }^{207} \mathrm{~Pb} /{ }^{204} \mathrm{~Pb}=15.49,{ }^{208} \mathrm{~Pb} /{ }^{204} \mathrm{~Pb}=35.35$

${ }^{*}$ In brackets, 2 standard errors shown as the least significant digits of ${ }^{207} \mathrm{~Pb} /{ }^{206} \mathrm{~Pb}$ ratios

Table 4. U-Pb analytical data for GGU sample 166815 (hydrothermal dissolution method). 


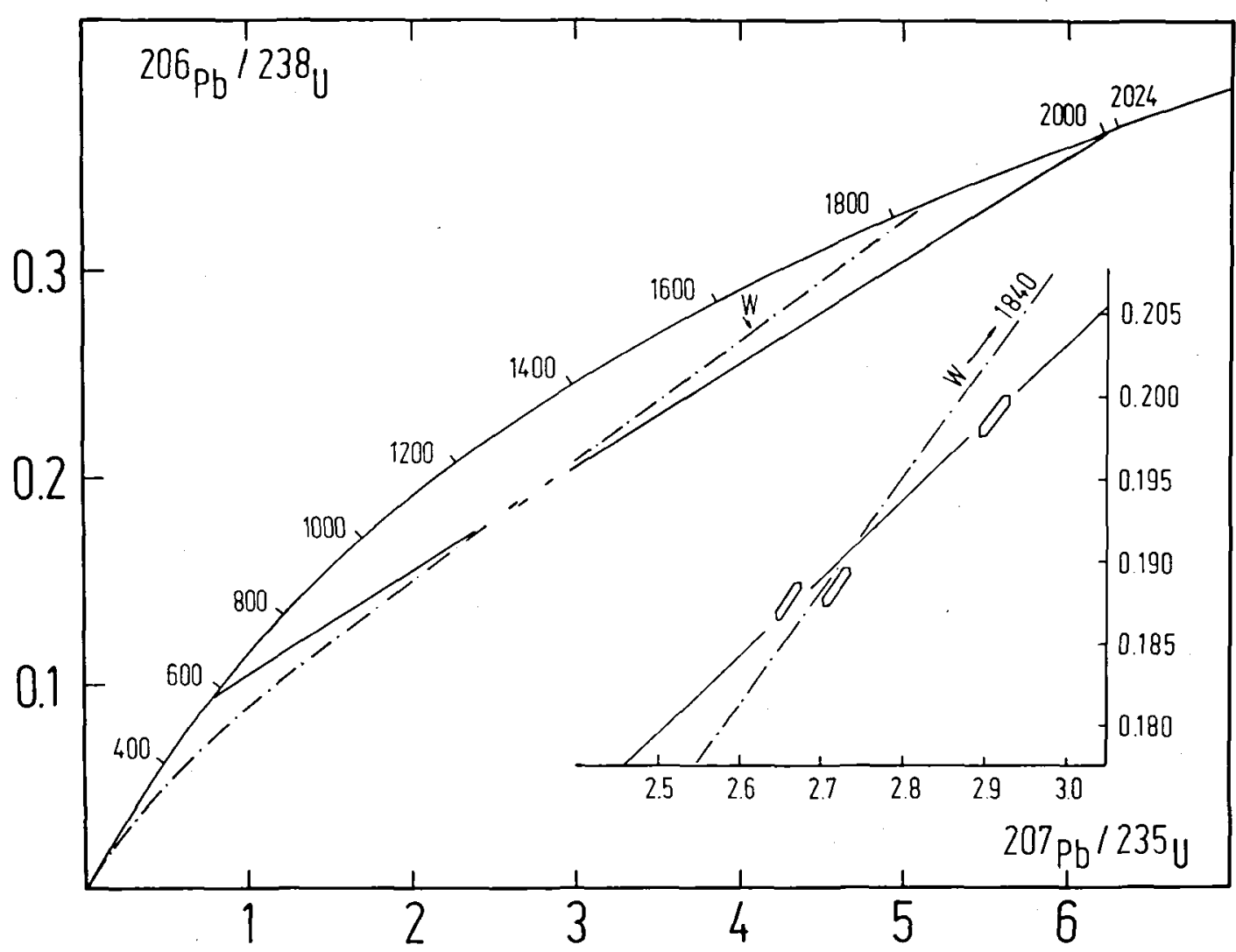

Fig. 4. ${ }^{206} \mathrm{~Pb} /{ }^{238} \mathrm{U}-{ }^{207} \mathrm{~Pb} /{ }^{235} \mathrm{U}$ plot for zircon fractions of the metagabbro (GGU sample 166815). The dash-dot line $\mathrm{W}$ is the best fit diffusion curve (Wasserburg 1963).

later low-grade overprinting during Caledonian time. The biotite-feldspar-whole-rock isochron of a fine grained pegmatite granite sample (103799) yields a Caledonian age of $402 \pm 8$ m.y. (fig. 5, table 2). However, the whole-rock-muscovite age of 1585 m.y. of the same sample is considerably higher than the age largely controlled by the biotite. It is unlikely that this age dates a geological event. Partial resetting of the intrusion age of $1835 \pm 50 \mathrm{~m} . \mathrm{y}$. during the Caledonian metamorphism is possible.

If the arguments of Jäger et al. (1967) are followed it can be concluded that the temperatures of the subsequent metamorphism did not exceed $500^{\circ} \mathrm{C}$.

It has also been recorded that the matrix of the presumed Vendian tillite shows overprinting under greenschist facies conditions (Steck 1971).
The presence of epidote (clinozoisite) garnet and sericite has been observed in samples of the pegmatite granite (table 5). These observations may imply that the area was exposed to a low medium-grade metamorphism subsequent to the regional metamorphism.

A Caledonian event is also indicated by the $\mathrm{Rb}-\mathrm{Sr}$ biotite age of $402 \pm 10$ m.y. (table 2 ) for an amphibolite (117363) in extreme eastern Charcot Land, very close to the projected position of the major thrust. The K-Ar age of a hornblende from the same sample yielded an age of $642 \pm 25$ m.y. (table 1) and is regarded as showing that the Caledonian event was not strong enough for complete resetting of the hornblende $\mathrm{K}-\mathrm{Ar}$ system.

The age of the major thrusting is assumed to be late Caledonian. The rock units east of, and 


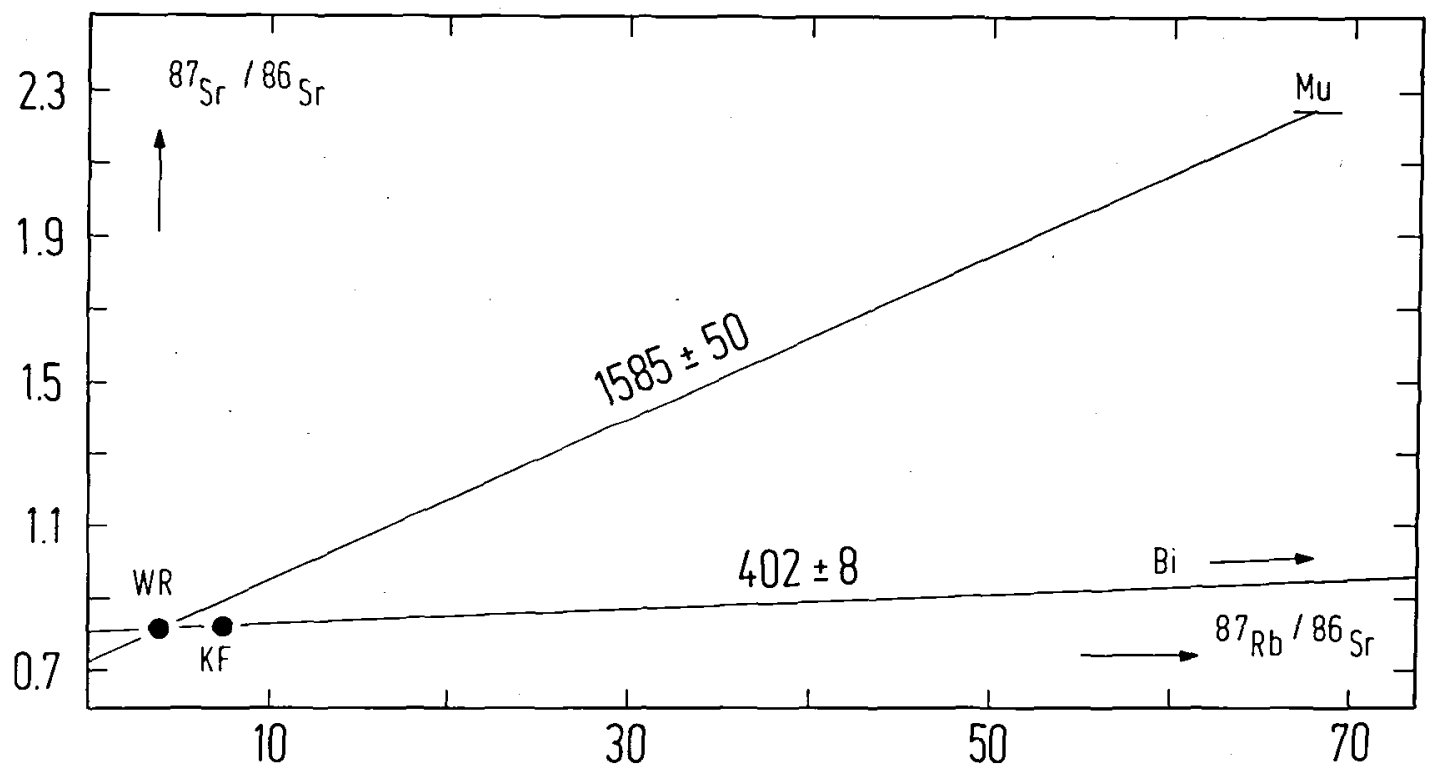

Fig. 5. Rb-Sr diagram for minerals separated from the pegmatite granite sample 103799.

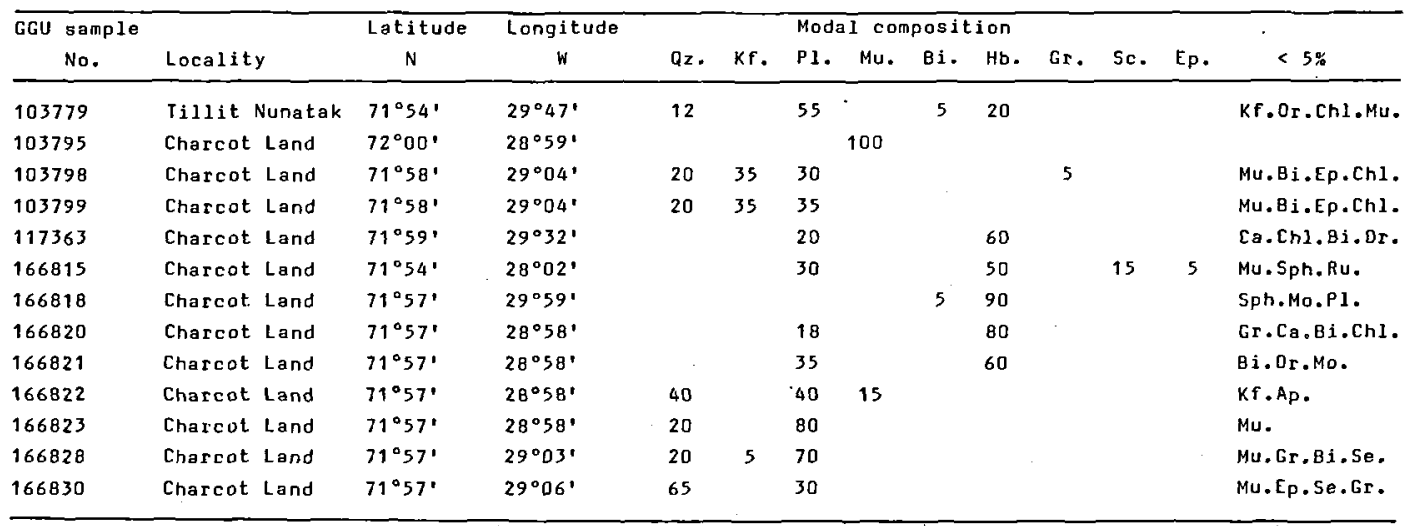

Qz.: quartz, Kf.: K-feldspar, PI.: plagioclase, Mu.: muscovite, Bi.: biotite, Hb.: hornblende,

Gr.: garnet, Sc.: scapolite, Chl.: chlorite, Ca.: carbonate, Ep.: epidote, Ru.: rutile, Sph.: sphene,

Mo.: monazite, Or.: ore minerals, Ap.: apatite, Se.: sericite

Table 5. Locality and petrography of samples.

above, the thrust have yielded many Caledonian $\mathrm{K}-\mathrm{Ar}$ and $\mathrm{Rb}-\mathrm{Sr}$ mineral ages (e.g. Rex \& Gledhill, 1974), but Caledonian regional metamorphism has not generally been sufficiently Gledhill 1974), but Caledonian regional metamorphism has not generally been sufficiently intense as to reset the $\mathrm{Rb}-\mathrm{Sr}$ whole rock isotopic systems of pre-Caledonian rock units; the Krummedal supracrustal sequence, for example, has yielded 1100 m.y. ages (Hansen et al., 1979). The rock units below the thrust in the Charcot Land window, while presumed to be parts of the Caledonian foreland, have not completely escaped the effects of Caledonian orogenesis. 


\section{Discussion and conclusions}

The infracrustal basement complex of Charcot Land is older than 2100 m.y., and probably Archaean. It may be compared in general terms to the Archaean Flyverfjord infracrustal complex which is widespread in the inner Scoresby Sund region east and south-east of Charcot Land.

The Charcot Land supracrustal sequence was probably deposited in the early Proterozoic, and suffered progressive regional metamorphism probably about 1900-1850 m.y. ago. No comparable supracrustal developments have been preserved within the East Greenland Caledonides, with the possible exception of the Eleonore Sø series $200 \mathrm{~km}$ to the north of Charcot Land whose age is unknown.

The two post-kinematic intrusions in Charcot Land were emplaced about 1840 m.y. ago. Several $\mathrm{Rb}-\mathrm{Sr}$ whole rock isochron ages in the range 1730-2000 m.y. have recently been obtained on granite and gneiss bodies in the infracrustal rocks north-east of Charcot Land within the Caledonian fold belt proper (Rex et al. 1976, Higgins et al. 1978). They may relate to the same early Proterozoic orogenic episode.

Charcot Land was affected by a weak Caledonian metamorphic overprint, possibly of irregular intensity. Greenschist facies metamorphism has been noted in the tillite matrix, and perhaps also affected the pegmatite granite, while the supracrustal rocks suffered low grade retrogression.

Acknowledgements. We wish to acknowledge helpful comments by A. Steck, A. B. Blaxland and N. Henriksen. U. Frick who made the Ar analyses and $M$. T. Bär ably assisted in the analytical work. This paper is published with the permission of the Director of the Geological Survey of Greenland.

\section{Dansk sammendrag}

Scoresby Sund områdets vestlige del udgøres af et tektonisk vindue, Charcot Land. $\mathrm{Rb}-\mathrm{Sr}, \mathrm{U}-\mathrm{Pb}$ og K-Ar dateringer af dette områdes bjergarter viser, at hovedmetamorphosen ikke som tidligere antaget er af kaledonisk alder, men fandt sted så tidligt som for 1840 millioner år siden.

Aldersbestemmelser af mineraler viser en svag kaledonsk overprægning af området. Temperaturen har dog i kaledonsk tid ikke overskredet $500^{\circ} \mathrm{C}$.

\section{References}

Goldich, S. S. \& Mudray, M. G. Jr. 1972: Dilatancy model for discordant $\mathrm{U} / \mathrm{Pb}$ zircon ages. Contrib. Recent Geochem. and Analyt. Chem. (A. P. Winogradov Volume) Nauka. Publ. Office: $415-418$.

Haller, J. 1971: Geology of the East Greenland Caledonides. Interscience Publishers, New York, 413 pp.

Hansen, B. T., Higgins, A. K. \& Bär, M. T. 1978: Rb-Sr and $\mathrm{U}-\mathrm{Pb}$ age patterns in polymetamorphic sediments from the southern part of the East Greenland Caledonides. Bull. geol. Soc. Danmark, 27: 53-60.

Henriksen, N. in press: The Charcot Land tillite, Scoresby Sund, East Greenland. In: Hambray, M. J. \& Harland, W. B. (eds.). Earth's pre-Pleistocene glacial record.

Henriksen, N. \& Higgins, A. K. 1969: Preliminary results of mapping in the crystalline complex around Nordvestfjord, Scoresby Sund, East Greenland, Rapp. Grønlands geol. Unders. 21: 5-21.

Higgins, A. K., Friderichsen, J. D., Rex, D. C. \& Gledhill, A. R. 1978: Early Proterozoic isotopic ages in the East Greenland Caledonian fold belt. Contrib. Mineral. Petrol. 67: 87-94.

Jäger, E., Niggli, E. \& Wenk, E. 1967: Rb-Sr Altersbestimmungen an Glimmern der Zentralalpen. Beiträge Geol. Karte Schweiz N.F. 134: 67 pp.

Pidgeon, R. T. 1978: 3450 m.y.-old volcanics in the Archaean layered greenstone succession of the Pilbara Block, Westem Australia. Earth Planet. Sci. Lett. 37: 421-428.

Rex, D. C. \& Gledhill, A. 1974: Reconnaissance geochronology of the infracrustal rocks of Flyverfjord, Scoresby Sund, East Greenland. Bull. geol. Soc. Denmark 23: 49-54.

Rex, D. C., Gledhill, A. R. \& Higgins, A. K. 1976: Progress report on geochronological investigations in the crystalline complexes of the East Greenland Caledonian fold belt. Rapp. Grønlands geol. Unders. 80: 127-133.

Rex, D. C., Gledhill, A. R. \& Higgins, A. K. 1977: Precambrian $\mathrm{Rb}-\mathrm{Sr}$ isochron ages from the crystalline complexes of inner Forsblads Fjord, East Greenland fold belt. Rapp. Gronlands geol. Unders, 85: 122-126.

Steck, A. 1971: Kaledonische Metamorphose der Präkambrischen Charcot Land Serie, Scoresby Sund, Ost-Grönland. Meddr Groniand, 192, 3: 69 pp.

Steiger, R. H. \& Henriksen, N. 1972: The geochronology of the Scoresby Sund area. Progress report 3: Zircon ages. Rapp. Grønlands geol. Unders., 48: 109-114.

Steiger, R. H. \& Jäger, E. 1977: Subcommission on geochronology: Convention on the use of decay constants in geo- and cosmo-chronology. Earth Planet. Sci. Lett. 36: 359-362.

Steiger, R. H., Hansen, B. T., Schuler, C., Bär, M. T. \& Henriksen, N. 1979: Isotopic age determinations revealing the polyorogenic nature of the southern Caledonian Fold Belt in East Greenland. $J l$ Geology, 87: 475-495.

Tilton, G. R. 1960: Volume diffusion as a mechanism for discordant lead ages. J. Geophys. Res. 65: 2933-2945.

Vogt, P. 1965: Zur Geologie von Südwest Hinks Land (Ostgrönland $71^{\circ} 31^{\prime} \mathrm{N}$ ). Meddr Grønland, 154, 5: $24 \mathrm{pp}$.

Wasserburg, G. J. 1963: Diffusion processes in lead-uranium systems. J. Geophys. Res. 68: 4823-4846.

Wetherill, G. W. 1963: Discordant uranium-lead ages - Pt. 2. Discordant ages resulting from diffusion of lead and uranium. J. Geophys. Res. 68: 2957-2965.

York, D. 1969: Least squares fitting of a straight line with correlated errors. Earth Planet. Sci. Lett. 5: 320-324. 